\title{
ОСНОВНЫЕ ИНФОРМАТИВНЫЕ ПРИЗНАКИ ФАЦИАЛЬНО-ГЕНЕТИЧЕСКИХ ТИПОВ ОТЛОЖЕНИЙ ПОЗДНЕГО ФАНЕРОЗОЯ ЮГО-ВОСТОКА ВОСТОЧНО-ЕВРОПЕЙСКОЙ ПЛАТФОРМЫ
}

\author{
3.А. Яночкина ${ }^{1}$, Т.Ф. Букина ${ }^{1}$ Е.Ф. Ахлестина ${ }^{1}$, Н.Я. Жидовинов ${ }^{1}$, А.В. Иванов ${ }^{2}$ \\ 1 Научно-исследовательский институт естественных наук \\ Саратовского государственного университета, \\ отделение геологии \\ 2 Саратовский государственный университет, \\ кафедра геоэкологии \\ E-mail: geoecologia@info.sgu.ru
}

\begin{abstract}
В статье рассмотрены информативные признаки фациальногенетических типов морских и континентальных отложений позднего фанерозоя юго-востока Восточно-Европейской платформы. Их анализ показывает необратимые тенденции уменьшения хемогенных образований от перми вверх по разрезу и увеличение роли терригенно-карбонатного, сапропелевого, кремнистокарбонатного биогенного осадконакопления.
\end{abstract}

Main Informative Characters of Facies-Genetic Types of the Late Phanerozoic Sediments from the South-East of the EasternEuropean Platform

ZA. Yanochkina, T.Ph. Bukina, E.Ph. Akhlestina, N.Ya.Zhidovinov, A.V. Ivanov

Main informative characters of facies-genetic types of the Late Phanerozoic marine and continental deposits for SE of the EasternEuropean platform are discussed. Their analysis has shown irreversible trends of decreasing of chemogenic formations from the Permian age to Recent as well as increasing of terrigenouscarbonate, sapropel and siliceous-carbonate biogenic sedimentation.

Многолетние комплексные исследования вещественного состава пород, проводимые авторами с применением гранулометрических, петрографо-минералогических, химико-спектральных, рентгеноструктурных и электронно-микроскопических анализов, позволили использовать при выделении генетических групп отложений более 60 признаков: текстурные и структурные характеристики пород, состав и особенности терригенных, карбонатных и кремнистых компонентов; диагенетические и палеогипергенные изменения песчано-алевритового материала и глинистой составляющей, наличие вулканокластики и др. Это, в свою очередь, дало возможность выявить основные информативные признаки морских, континентальных и переходных (от морских к континентальным) ге-

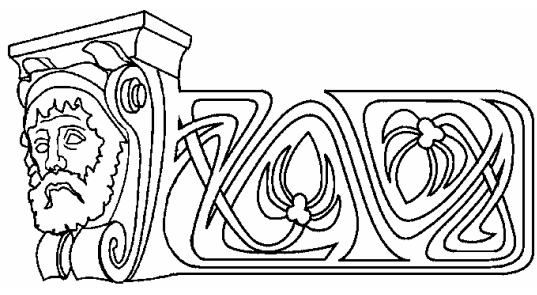

нетических групп осадков позднего фанерозоя [1-11].

Каждой генетической группе осадков присущи свои специфические черты, отражающие влияние тектонических и климатических факторов. Эти черты являются интегральной характеристикой всех процессов, участвующих в седиментогенезе и литогенезе осадочных толщ, формировавшихся в условиях аридного, семиаридного и гумидного климата.

Генетические группы отложений
морских бассейнов седиментации

Морские образования, широко развитые на различных хроностратиграфических уровнях, представлены авандельтовыми прибрежными отложениями активного и малоподвижного мелководья, заливов и лагун, открытого морского бассейна, удаленных от побережья относительно глубоководных и депрессионных участков моря. В каждой из этих групп выделяется ряд фаций, сочетание которых, а также вещественный состав однотипных разновозрастных осадков меняется во времени.

Для генетических групп отложений бассейнов ранней перми основными информативными признаками являются:

1) широкое распространение органогенно-карбонатных фаций, представленных биогермами, сложенными водорослями - тубуфитами, колониями кораллов и биостромными строматолитовыми образованиями; 
2) наличие значительного количества хемогенных образований: карбонатных, ангидритовых, галитовых;

3) кварцево-граувакковый или граувакково-аркозовый состав терригенного материала с устойчивой гранат-рутил-цирконовой ассоциацией тяжелых минералов;

4) хлорит-гидрослюдистый состав глинистых компонентов;

5) повсеместное развитие постседиментационных процессов: доломитизации водорослевых известняков, сохранивших реликтовые органогенные структуры, ангидритизации пород биогермного типа, реже стилолитизации.

Для генетических групп осадков морского бассейна поздней перми, связанного с раннеказанской трансгрессией бореальных вод, характерны следующие информативные признаки:

1) присутствие органогенных, органогенно-терригенных и известково-глинистых отложений активного мелководья с фауной брахиопод, пелеципод, фораминифер и мшанок, характерных для водоемов нормальной солености;

2) наличие биохемогенных мелкозернистых, оолитовых и пелитоморфных известково-доломитовых образований, сохранивших реликтовые биоморфные структуры;

3) наличие тонкогоризонтальной слоистости в алевритово-глинистых и глинистых тонкодисперсных осадках, отражающих спокойную гидродинамику вод бассейна седиментации;

4) преобладание сероцветных окрасок над красноцветными за счет присутствия тонкодисперсного пирита.

Для генетических групп осадков морского бассейна раннего триаса (оленекский век) характерны следующие информативные признаки:

1) преимущественное развитие терригенных и терригенно-карбонатных отложений прибрежного мелководья при подчиненном значении карбонатных фаций открытого нормально-морского бассейна с фауной аммоноидей, остракод, двустворчатых моллюсков и рыб;
2) присутствие смешанных известковопесчано-алевритово-железисто-глинистых биотурбированных осадков иловых впадин;

3) наличие в прибрежных зонах известковых гравелитов, аналогичных «известняковым конгломератам», сложенным остатками голотуриеподобных организмов, распространенных в оленекском бассейне Мангышлака и Устюрта;

4) преобладание в наиболее удаленных от берега участках остракодово-кокколитовых известняков с реликтовыми кокколитовыми наноструктурами;

5) значительное преобладание среди глинистых минералов аллотигенного хлорита и гидрослюды;

6) локальное развитие диагенетического доломита и фрамбоидального пирита в участках, обогащенных сапропелевым органическим веществом.

Для генетических групп осадков среднетриасового морского бассейна (в период максимальной трансгрессии океанических вод, постепенного увлажнения и гумидизации климата) свойственны следующие черты:

1) преимущественное развитие солоновато-водных морских терригенных и терригенно-карбонатных отложений прибрежного мелководья и значительное органогенное карбонатонакопление в открытом морском мелководье;

2) наличие пелециподово-остракодовых известняков и рифогенных построек;

3) присутствие сгустково-комковатых известковых образований, возникших, повидимому, за счет переотложения суспензионными потоками комочков слабо литифицированного глинисто-известкового ила со дна водоема;

4) наличие прослоев ракушняковых «банок» в терригенных прибрежных осадках;

5) снижение в осадках активного мелководья полимиктовости алевритово-песчаного материала и степени его измененности;

6) преобладание среди глинистых минералов структурно «деградированных» гидрослюд и хлоритов;

7) появление значительного количества углефицированных органических остатков; 
8) образование в восстановительных средах аутигенного пирита, а на геохимическом барьере пресных и соленых вод - барита;

9) наличие диагенетического кальцита и доломита.

Для генетических групп осадков морских бассейнов средней и поздней юры присущи следующие информативные признаки:

1) преобладание биогенного осадконакопления с подчиненным значением терригенного, выраженного в накоплении преимущественно глинистого и алевритовоглинистого материала при низком темпе седиментации;

2) породообразующее значение кокколитофорид, фораминифер, участие в составе отложений остатков многочисленной морской фауны и особенно аммонитов, послуживших основой для стратификации и корреляции разрезов;

3) высокая концентрация в осадках сапропелевого органического вещества (волжский ярус), формировавшихся в условиях морского стагнированного бассейна;

4) полиминеральный состав (гидрослюда, хлорит, монтмориллонит и др.), высокая интенсивность трансформации глинистого вещества, наличие каолинита и фрагментов кор выветривания, приносимых реками с выравненных участков суши;

5) олигомиктовый, локально-полимиктовый состав псаммитово-алевритовых осадков;

6) периодическое появление лито- и витрокластического материала с признаками цеолитизации наиболее обогащеных этим материалом прослоев;

7) высокие концентрации слюд в осадках водоемов конечного стока;

8) низкое содержание акцессорных минералов, связанное как с незначительным поступлением терригенного материала, так и с отсутствием условий для естественного шлихования тяжелых фракций;

9) образование диагенетических аутигенных минералов: пирита в глубоководных фациях, сидерита - в мелководных (на геохимическом барьере слияния пресных и соленых вод), глауконита и фосфатов - в песчаных осадках прибрежного мелководья на фосфатном шельфе;
10) развитие раннедиагенетического процесса декарбонатизации исходно известковых осадков, определяемых по реликтовым кокколитовым наноструктурам, что наиболее ярко выражено в алевритовых глинах морского мелководья, опресненных участков и в осадках, обогащенных органическим веществом.

Для генетических групп осадков раннемелового времени информативными признаками являются следующие:

1) преобладание прибрежно- и мелководно-морских фаций, отсутствие угленосных образований и локально ограниченное проявление сапропеленакопления (апт);

2) терригенный характер прибрежномелководных и мелководно-морских осадков с возрастанием зрелости песчаного материала от олигомиктового в валанжинском веке до мономинерального кварцевого (в альбе);

3) исчезновение в составе осадков фрагментов кор выветривания в связи с их дезинтеграцией на путях транспортировки и в бассейнах с активной гидродинамикой;

4) увеличение роли монтмориллонита и незначительное содержание каолинита в комплексе глинистых минералов, обусловленное сменой физико-химических условий среды седиментации;

5) повышение содержания акцессорных минералов с локальным образованием в мелководно-морских осадках титан-циркониевых россыпей в результате естественного шлихования материала;

6) снижение интенсивности пиритизации осадков, низкий уровень сидеритизации при сохранении условий для формирования глауконита и фосфатов в прибрежной зоне;

7) декарбонатизация исходно известковых осадков опресненных заливов и морского мелководья на стадии раннего диагенеза как признак активной генерации сапропелевого органического вещества при неблагоприятных условиях его захоронения.

Для генетических групп осадков морского бассейна позднего мела информативными признаками являются следующие:

1) преимущественно биогенный характер карбонатных и кремнистых осадков всех фациальных зон; 
2) породообразующее значение в известковых осадках прибрежного мелководья толстостенных моллюсков, главным образом пелеципод (формирующих слои известняков в туроне-коньяке и устричные банки на разных уровнях); а в относительно глубоководных участках - планктонных фораминифер и кокколитофорид;

3) преимущественно радиоляриевый состав кремнистых осадков глубоководных участков морских бассейнов;

4) высокая зрелость песчано-алевритовых прибрежно-мелководных осадков, породообразующее значение в которых имеет кварц и устойчивый комплекс акцессорных минералов;

5) титан-циркониевая ассоциация акцессорных минералов алевритово-песчаных осадков мелководья, отмелей с образованием на отдельных временных уровнях значительных концентраций путем естественного шлихования;

6) преимущественно монтмориллонитовый состав глинистых минералов в мелководных и относительно глубоководных зонах бассейнов;

7) смешаннослойный монтмориллонитгидрослюдистый состав глинистых минералов в осадках открытого мелководья (алевроглино-песках, алевро-глино-силицито-известняках);

8) гидрослюдистый состав глинистых минералов песчаных осадков прибрежного и открытого мелководья;

9) присутствие пепловой витрокластики (особенно в составе сантонских алевритовоглинисто-кремнистых осадков), способствовавшей развитию кремниевого планктона и постседиментационному минералообразованию, в частности цеолитовому;

10) высокие концентрации глауконита в алевритово-песчаных осадках мелководья сеноманского бассейна, в алевритово-известково-глинисто-кремнистых осадках мелководья и углубленных участков сантон-маастрихтского бассейнов;

11) образование залежей и проявлений желваковых фосфоритов в гравийно-галечнопесчаных и грубопесчаных осадках прибрежного мелководья в бассейнах различных временных уровней;
12) наличие пластовых белых фосфоритов (вольскитов) в известковых биогенных осадках прибрежно-мелководных участков туронского (?) бассейна;

13) локальное ожелезнение песчаных осадков прибрежно-мелководных участков сеноманского и сантонского бассейнов с образованием линз и пластов железистых песчаников.

Для генетических групп осадков палеогена основными информативными признаками являются следующие:

1) более широкое, по сравнению с поздним мелом, распространение кремнистых осадков депрессионных участков морского бассейна;

2) породообразующее значение диатомовых водорослей;

3) присутствие пепловой витрокластики кислого состава в прибрежно-мелководных песчаных осадках (пролейская свита) и базальтового состава в алевро-глинистокремнистых осадках (вешенская свита) депрессионных зон палеоценовых бассейнов;

4) высокая зрелость и преимущественно кварцевый состав песков и алевритов прибрежных и мелководных частей бассейна;

5) титан-циркониевые ассоциации минералов с образованием высоких концентраций (россыпей) в алевритах и мелкозернистых песках активного морского мелководья с дифференцированным рельефом дна;

6) кианит-силлиманит-ставролитовая ассоциация минералов для средне- и крупнозернистых разностей песков прибрежного мелководья;

7) дифференцированное распределение глинистых минералов от преимущественно монтмориллонитовых глин относительного глубоководья к смешанослойным монтмориллонит-гидрослюдистым алевритовоглинистым, алевритово-глинисто-песчаным осадкам открытого мелководья и гидрослюдисто-глауконитовым пескам прибрежного мелководья;

8) незначительное, по сравнению с поздним мелом, распространение известковых осадков с породобразующим значением планктонных организмов (фораминифер и кокколитофорид) в относительно глубоководных участках палеогенового морского бассейна субокеанического типа; 
9) широкое проявление постседиментационных изменений осадков с образованием двух господствующих парагенезов - полиморфных модификаций кремнезема (по ряду: биогенный опал, вулканогенный материал кремнистый, алюмо-кремнистый гидрогель опал, кристобалит - кристобалит, тридимит халцедон - кварц) и цеолитово-глинистокристобалитового парагенеза (кремнистый гидрогель + цеолиты + смектит, или глауконит + кристобалит);

10) локальное проявление постседиментационных процессов с образованием фосфоритовых залежей, глауконититов, линз и пластов железистых и кремнистых песчаников промышленного значения.

Для генетических групп осадков неогена основными информативными показателями являются следующие:

1) преимущественно терригенный характер осадков;

2) преобладание в прибрежно-мелководных участках сарматского, мэотического, понтического бассейнов известняков-ракушняков с фауной пелеципод, а в мелководноморских - карбонатно-глинистых отложений;

3) олигомиктовый и мономиктовый состав песков и алевритов;

4) косая слоистость в песчано-алевритовых мелководных и прибрежно-мелководных осадках и горизонтальная тонкая - в глинистых относительно глубоководных;

5) гидрослюдистый состав с примесью хлорита мелководных глин и преимущественно монтмориллонитовый - относительно глубоководных;

6) циркон-рутил-гранат-турмалин-эпидотовая ассоциация минералов мелководных терригенных осадков;

7) наличие известкового кокколитового шлама, переотложенного из мела и палеогена, в известково-глинистых и карбонатных морских мелководных осадках (сармат, мэотис, понт);

8) присутствие в относительно глубоководных глинах гнезд пирита, а также мельниковита, возникающего в условиях недостаточности реакционно-активной сульфидной серы;
9) наличие сидерита в глинистых осадках мелководья и глауконита в алевритах и песках прибрежных зон.

\section{Генетические группы континентальных и переходных (от морских к континентальным) отложений позднего фанерозоя}

Континентальные отложения получили наибольшее развитие в поздней перми, раннем триасе, позднем триасе, ранней юре, поздней юре и неогене. На каждом уровне они характеризуются своеобразным набором фациально-генетических групп и их вещественных характеристик.

Для позднепермского - раннетриасового континентального осадконакопления, проходившего в условиях засушливого аридного климата, при значительном развитии процессов механической дезинтеграции пород на источниках сноса характерны следующие основные информативные признаки:

1) присутствие полного генетического ряда фаций: эоловых, делювиально-пролювиальных, озерных и аллювиальных со своими характерными особенностями;

2) полимиктовый состав и слабая измененность терригенных компонентов;

3) первичная красноцветность пород, связанная с наличием маловодных окислов железа;

4) незначительное содержание в породах органического вещества и углефицированных растительных остатков в связи со слабым развитием растительного покрова на окружающей суше и окислительными условиями среды седиментации;

5) гидрослюдисто-хлоритовый состав гли-нистых компонентов;

6) наличие в сохранившихся фрагментах красноцветных почв новообразований гидроокислов железа и минерализованных карбонатных нитевидных корней растений;

7) присутствие анальцима, возникшего в определенных геохимических обстановках за счет разложения пирокластики.

Для позднетриасового-раннеюрского континентального осадконакопления, проходившего в условиях гумидного климата и широкого развития кор выветривания на пенепленизированной суше, характерны следующие информативные признаки: 
1) широкое развитие генетических групп аллювиальных, озерных и озерно-болотных фаций;

2) преобладание олигомиктовых и присутствие в отдельных случаях мономинеральных кварцевых песчаных осадков, содержащих интенсивно измененные обломки пород и минералов;

3) преимущественно сероцветная окраска пород;

4) значительное содержание органического вещества и углефицированных растительных остатков вплоть до образования углистых прослоев, связанных с широким развитием растительного покрова на суше;

5) обязательное присутствие аллотигенного каолинита вместе с монтмориллонитгидрослюдистыми ассоциациями глинистых минералов как результат разрушения на источниках сноса зрелых кор выветривания;

6) появление аутигенного каолинита показателя кислых сред, возникающих в условиях заболоченных озер;

7) присутствие пропластков сидерита, связанного с перераспределением железа в условиях углекислотного заражения придонных вод, а также конкреций сидерита и анкерита в сохранившихся фрагментах гумидных палеопочв.

Для переходных фациально-генетических групा осадков среднеюрско-позднеюрского времени, к которым относятся образования лагун и заливов, а также мелких озерно-болотных бассейнов на равнине, периодически заливаемой морем, характерны следующие информативные признаки:

1) высокие концентрации углистого вещества (аален, байос), накапливавшегося в условиях гумидного климата, и сапропелевого органического вещества (волжский ярус), формировавшегося в условиях постепенной аридизации климата;

2) декарбонатизация известковых компонентов осадков в опресненных участках бассейна;

3) кварцевый состав песчаного материала аллювиальных и авандельтовых образований (гнилушкинская свита);

4) присутствие в пелитовых фракциях авандельтовых песков фрамбоидального пирита, который формируется при насыщении осадков морскими водами, содержащими сульфат-ион;

5) локальное развитие на островной суше красноцветных латеритных почв (СольИлецк), пронизанных ходами мелких червей, содержащих гиббсит, а также свободные формы алюминия.

В палеогене выделяются переходные фациально-генетические группы континентально-морских образований, представленных аллювиально-прибрежными авандельтовыми и пляжевыми отложениями. Для них характерны:

1) сложная косая разнонаправленная слоистость;

2) разнозернистый состав песков с существенной примесью галечно-гравийного материала (в отдельных слойках до 40\%) (верхнесаратовская подсвита, антиповская свита);

3) преимущественно кварцевый состав песка и гравия;

4) силлиманит-дистен-ставролитовая ассоциация акцессорных минералов;

5) кварц-халцедоновый и фосфоритовый состав гальки в прослоях, обогащенных гравийно-галечным материалом;

6) насыщенность отложений флористическими углефицированными и окремнелыми остатками: детритом, листьями, обломками целых стволов древесины;

7) локальное проявление постседиментационных процессов в виде ожелезнения, окремнения, фосфатизации, сульфатизации осадков;

8) наличие в прибрежных зонах конденсированных слоев, обогащенных переотложенными фосфоритами;

9) континентальные отложения представлены рыхлыми галечниками и песками, формирование которых связано с перемывом местных пород.

Для переходных фациально-генетических групп осадков неогена свойственны лиманные и озерные песчано-алевритовые глины гидрослюдистого состава с рассеянными гнездами сидерита и прослоями кварцевых косо- и горизонтально-слоистых песков. В речных врезах формировались аллювиальные галечно-гравийные песчаные образования. Пески кварцевые разнозернистые с грубой косой слоистостью. Галька представ- 
лена кварцем, обломками кремней и известняков карбона и перми; обломками опок, песчаников, мела, мергелей из меловых и палеогеновых отложений.

Вышеизложенное свидетельствует о необратимых изменениях вещественных характеристик от древних осадков к современным, находя свое отражение в преобразовании генетических групп осадков и их объемов с общей тенденцией уменьшения роли хемогенных образований от перми вверх по разрезу. Наблюдается увеличение роли терригенно-карбонатного, сапропелевого, кремнисто-карбонатного биогенного осадконакопления с последующим переходом в неогене и эоплейстоцене к накоплению преимущественно терригенных осадков высокой зрелости. Практическая значимость исследований заключается в возможности использования вещественных информативных критериев при расчленении осадочных толщ изучаемого региона, разработки критериев межрегиональной корреляции разрезов, а также для прогноза полезных ископаемых.

\section{Библиографический список}

1. Ахлестина Е.Ф., Курлаев В.И. О цеолитоносности эоценовых отложений Саратовского и Волгоградского Поволжья // Геология, физико-химические свойства и промышленное применение цеолитов. Тбилиси, 1985. С.41-45.

2. Ахлестина Е.Ф., Курлаев В.И. Эоценовые пепловые отложения Саратовского и Волгоградского Поволжья // Вопросы геологии Южного Урала и Поволжья (минер., петрогр., геохим.). Саратов, 1988. С.119-130. Деп. в ВИНИТИ 21.09.88 г. №7068-В88.
3. Бондаренко Н.А. Минералого-петрографическая характеристика верхнемеловых пород Саратовско-Волгоградского междуречья Волги и Медведицы // Вопр. стратиграфии и палеонтологии. Саратов, 1980. Вып.5. С.89-107.

4. Букина Т.Ф., Яночкина 3.А., Суетнова Н.А. Наноструктуры как показатели диагенетических процессов в горючих сланцах Волжского бассейна // Геохимия, минералогия и литология черных сланцев. Сыктывкар, 1987. С.128129

5. Муравьев В.И., Цеховский Ю.Г., Ахлестина Е.Ф. и др. Вулканические пеплы базальтового состава из палеоценовых отложений Южного Поволжья // Литология и полезные ископаемые. 1997. №3. С.327-330.

6. Яночкина 3.A. Информативные минералы и элементы триасовых отложений Саратовского Заволжья // Вопросы геологии и нефтегазоносности некоторых платформенных и складчатых областей. Элиста, 1972. С.99-114.

7. Яночкина 3.А., Букина Т.Ф. Об остатках шиповатых микроорганизмов и следах их жизнедеятельности в триасовых отложениях Мангышлака и Устюрта // Стратиграфия и палеонтология триасовых отложений Мангышлака и Устюрта. М., 1984. С.123-127.

8. Яночкина 3.А., Букина Т.Ф. Информативные признаки граничной зоны перми и триаса (Южн. Междуречье УралВолга ) // Геологические науки - 99: Тр. Межвед. науч. конф. Саратов, 1999. С.54-57.

9. Яночкина 3.А., Гуцаки В.А., Иванов А.В. и др. Литологофациальные особенности отложений позднего фанерозоя юго-востока Восточно-Европейской платформы // Tp. НИИ геологии Сарат. гос. ун-та. Саратов, 2000. Нов. серия. Т.5. $114 \mathrm{c}$.

10. Яночкина 3.А., Жидовинов Н.Я., Ахлестина Е.Ф. и др. Фациально-генетический анализ отложений палеобассейнов фанерозоя юго-востока Русской платформы // Там же. 1999. T.1. C.33-43.

11. Яночкина 3.А., Букина Т.Ф., Ахлестина Е.Ф. и др. Наиболее значимые событийные уровни, выраженные в вещественном составе отложений позднего фанерозоя юговостока Восточно-Европейской платформы // Изв. Сарат. ун-та. Нов. сер. Саратов, 2004. Т.4, вып.1-2. С.63-79. 